\title{
Feeding ecology of the common bottlenose dolphin, Tursiops truncatus, in southern Brazil: analyzing its prey and the potential overlap with fisheries
}

\author{
Lucas Milmann 1,2,3*, Daniel Danilewicz ${ }^{1,4}$, Rodrigo Machado ${ }^{1,5}$, Roberta Aguiar dos Santos ${ }^{6,7}$, \\ Paulo Henrique Ott ${ }^{1,2}$
}

\author{
${ }^{1}$ Grupo de Estudos de Mamíferos Aquáticos do Rio Grande do Sul (GEMARS). \\ (Rua Machado de Assis, 1456 - Bairro Sulbrasileiro, Osório, RS, CEP: 95520-000) \\ ${ }^{2}$ Universidade Estadual do Rio Grande do Sul (UERGS). \\ (Rua Machado de Assis, 1456 - Sulbrasileiro, Osório, RS, CEP: 95520-000) \\ ${ }^{3}$ Programa de Pós-graduação em Zoologia, Universidade Estadual de Santa Cruz (UESC). \\ (Campus Soane Nazaré de Andrade - Rod. Jorge Amado, km 16 - Salobrinho, Ilhéus, BA, CEP: 45662-900) \\ ${ }^{4}$ Instituto Aqualie. \\ (Av. Dr. Paulo Japiassu Coelho, 714 - Sala 206 - Juiz de Fora, MG, CEP: 36033-310) \\ ${ }^{5}$ Universidade Federal do Rio Grande do Sul, Programa de Pós-Graduação em Biologia Animal. \\ (Av. Bento Gonçalves, 9500, Bloco IV, Prédio 43435, Sala 219, Porto Alegre, RS, CEP: 91501-970) \\ ${ }^{6}$ Instituto Chico Mendes de Conservação da Biodiversidade. \\ (Estr. Hisaichi Takebayashi, 8600, Atibaia, SP, CEP: 12952-011) \\ ${ }^{7}$ Centro Nacional de Pesquisa e Conservação da Biodiversidade Marinha do Sudeste e Sul (CEPSUL). \\ (Av. Ministro Victor Konder, 374 - Centro, Itajaí, SC, CEP: 88301-700) \\ *Corresponding author: 1cmilmann@gmail.com
}

The common bottlenose dolphin (henceforth referred to as the bottlenose dolphin), Tursiops truncatus (Montagu 1821), is of worldwide distribution in tropical and temperate regions in both coastal and oceanic waters (WELLS; SCOTT, 2009). In the Southwestern Atlantic Ocean (SWA), the species occurs from the northern Brazilian coast (SICILIANO et al., 2008) to Tierra del Fuego, Argentina (GOODALL et al., 2011).

Despite the wide distribution of the species in the SWA, information on the bottlenose dolphin's feeding habits in this region is relatively sparse. Only a comparatively small number of specimens thus far been analyzed in the few studies published to date, mainly in southeastern Brazil (DI BENEDITTO et al., 2001; GURJÃO et al., 2004; SANTOS; HAIMOVICI, 2001, SANTOS et al., 2002; MELO et al., 2010).

In the southern most areas of the Brazilian shore, the bottlenose dolphin is commonly sighted very close to the shore, usually within less than $0.5 \mathrm{~nm}$ of it, and inside estuaries and river mouths (e.g. SIMÕES-LOPES, 1991; DI TULLIO et al., 2015). In some of these estuaries, bottlenose dolphins cooperate with the artisanal fishermen's fishing activity, mainly during the mullet (Mugil spp.) fishing season (e.g. SIMÕES-LOPES et al., 1998; ZAPPES et al., 2011; DAURA-JORGE et al., 2013).

This coastal bottlenose population dolphin is known to be under threat in various ways, including gill net fishing and habitat degradation (VAN BRESSEM et al., 2007, 2015; FRUET et al., 2012). As a result, this population is currently classified as vulnerable (VU) at the regional level (RIO GRANDE DO SUL, 2014).

Since knowledge of diet is fundamental to understanding habitat preferences, trophic interactions and potential competition between marine mammals and fisheries for available marine food resources (e.g., KASCHNER; PAULY, 2005; BOYD, 2010; DUNSHEA et al., 2013), new qualitative and quantitative data on bottlenose dolphin feeding ecology in southern Brazil are presented here.

The stomach contents of 21 stranded bottlenose dolphins were collected by a marine mammal research team (Grupo de Estudos de Mamíferos Aquáticos do Rio Grande do Sul - GEMARS) during systematic beach surveys (mostly monthly) along the central-northern coast of Rio Grande do Sul, southern Brazil, between November 1991 and October 2008. The area surveyed covered about $250 \mathrm{~km}$ of exposed sandy beaches, from Torres $\left(29^{\circ} 19^{\prime} \mathrm{S}\right.$, $\left.49^{\circ} 43^{\prime} \mathrm{W}\right)$ to the Lagoa do Peixe National Park (31 ${ }^{\circ} 15^{\prime} \mathrm{S}$, $\left.50^{\circ} 54^{\prime} \mathrm{W}\right)$.

The animals were classified, in the field, by sex and standard body length. The stomach of each dolphin was removed from its abominal cavity during the dissection procedure, for further examination. Voucher skulls were collected for all specimens and deposited at GEMARS's 
scientific collection. In the laboratory, the three stomach chambers of each dolphin were examined and their contents washed through $0.3 \mathrm{~mm}$ and $1.0 \mathrm{~mm}$ mesh sieves. The cephalopod beaks found were stored in $70 \%$ ethanol. Otoliths and fish bones were stored dry. Fish otoliths and cephalopod beaks were identified as far as possible to the species level, using local reference collections (e.g. CEPSUL/ICMBio, for cephalopod beaks) and identification guides (e.g., MENEZES; FIGUEIREDO, 1980; WAESSLE et al., 2003; ROSSI-WONGTSCHOWSKI et al., 2014).

The minimum number of ingested fish in each stomach was estimated by the greater number of either right or left otoliths. When the side could not be determined, the total amount of those structures was divided by two. For the cephalopods, the higher number of either upper or lower beaks was considered for quantifying the amount of prey ingested. Measurements of the prey remains (i.e. otoliths and cephalopod beaks) were gathered using a stereomicroscope with ocular micrometer and precision of $0.1 \mathrm{~mm}$. The prey's total length $(\mathrm{mm})$ and biomass $(\mathrm{g})$ were back calculated using the size of these structures (i.e. otoliths and cephalopod beaks) and published regression equations (SANTOS; HAIMOVICI, 1998; HAIMOVICI; VELASCO, 2000; WAESSLE et al., 2003). Otoliths that were severely eroded were counted but not included to estimate prey length and mass. In these cases, these measurements were averaged from data of intact structures of the same species. The correlation between the size (i.e. total body length) of bottlenose dolphins and their prey was tested using Spearman rank correlation.

The numerical frequency $(\% \mathrm{~N})$ and frequency of occurrence $(\% \mathrm{FO})$ were defined as the percentage of each prey ingested and the number of stomachs containing a given prey, respectively. The relative importance of each prey in the diet of bottlenose dolphins was assessed using the index of relative importance (IRI), expressed both in the traditional way $(\mathrm{IRI}=[\% \mathrm{~N}+\%$ Prey biomass $] \mathrm{x}[\% \mathrm{FO}]$; PINKAS et al., 1971), as well as on a percentage basis $\left(\%\right.$ IRI $_{i}=100$ IRI $_{i} / \Sigma I_{\text {IRI }}$; CORTÉS, 1997). In calculating IRI values, the unidentified teleosts were excluded from the analysis, since it was not possible to estimate their biomass. To reduce possible bias from differential rates of digestion among species (e.g., BOWEN, 2000), indices were calculated separately for each major taxonomic group (i.e. fishes and cephalopods).

Indices were calculated for prey species, as well as for ecological groups. Ecological groups were defined according to prey habits and vertical distribution (e.g.
HAIMOVICI; PEREZ, 1991; CARVALHO-FILHO, 1999; HAIMOVICI; KLIPPEL, 2002). Demersal species were the prey associated with the bottom and pelagic species were the ones using the whole water column, excepting the bottom. Species that were present in both depth zones were classified as demersal-pelagic.

To investigate potential dietary changes over time, a non-parametric test (chi-squared) was used to compare the contributions ( $\% \mathrm{~N}$ and $\% \mathrm{FO}$ ) of the main prey species for two pooled periods $(1991-2002, \mathrm{n}=11 ; 2003-2008, \mathrm{n}=10)$. Direct comparisons of the IRI of the most important prey items were also made for these two periods.

Of the 21 bottlenose dolphins analyzed, 13 were male, three were female and five were of undetermined sex. The total length of the measured specimens ranged from 205.5 to $346.0 \mathrm{~cm}$ (median $=276.0 ; \mathrm{SD}=45.6 ; \mathrm{n}=16)$. The majority of the bottlenose dolphins were found between November and April (spring and summer) $(\mathrm{n}=14)$, while May to October (autumn and winter) accounted for only seven individuals.

A total of 1,493 ingested prey items, including 1,479 otoliths and 14 cephalopod beaks, were found in the stomachs of the dolphins. Due to the high degree of digestion, it was not possible to identify 55 otoliths, comprising 30 teleosts (Table 1). The prey items identified numbered at least 804, including 793 (98.6\%) bony fishes and 11 cephalopods (1.4\%) (Table 1). Regarding marine debris, only one small piece of nylon was found in the stomach contents of one dolphin.

The diversity of prey ingested represents a total of 15 fish species belonging to eight families (Table 1). Cephalopods were represented by three species (Argonauta nodosa, Doryteuthis plei and D. sanpaulensis). The most important family of fish found was Sciaenidae, accounting for eight species. All the other families were represented by one member only. The diversity of prey items ingested by each dolphin varied from one to 12 species $(\mathrm{x}=4.80 ; \mathrm{SD}=2.87)$ (Table 1$)$.

The most important teleosts, by \%IRI, were: Trichiurus lepturus, Paralonchurus brasiliensis and Mugil cf. liza. In addition, four species showed a relatively high frequency of occurrence $(\% \mathrm{FO}>25)$ : Urophycis brasiliensis, Menticirrhus littoralis, Cynoscion guatucupa and Macrodon atricauda, although they did not reach high $\%$ IRI values $(\%$ IRI $<5)$ (Table 1$)$.

Diet composition has not changed drastically over the years, since 13 out of 18 prey species were consumed in both periods (i.e. 1991-2002 and 2003-2008). No statistical 
Table 1. Prey species found in the stomach content of common bottlenose dolphins $(\mathrm{n}=21)$ from the central-northern coast of Rio Grande do Sul, southern Brazil, from 1991 to 2008. Key to abbreviations: $E G=$ Ecological group, DP= Demersal-pelagic, $\mathrm{D}=$ Demersal, $\mathrm{P}=$ Pelagic, $\mathrm{N}=$ Number, $\% \mathrm{~N}=$ Numerical frequency, $\mathrm{FO}=$ Frequency of occurrence, $\% \mathrm{FO}=\mathrm{Percentage}$ frequency of occurrence, $\mathrm{W}=$ Biomass, $\% \mathrm{~W}=$ Percentage biomass, IRI = Index of Relative Importance. Bold type indicates the analysis for the largest taxonomic groups (the values within brackets resulted from a combined analysis of both groups).

\begin{tabular}{|c|c|c|c|c|c|c|c|c|c|}
\hline TAXON & Family & EG & $\mathrm{N}$ & $\% \mathrm{~N}$ & FO & $\% \mathrm{FO}$ & $\mathrm{W}$ & $\% \mathrm{~W}$ & IRI \\
\hline Teleosts & & & 793 & $100(98.63)$ & 21 & 100 & 72,259 & $100(99.38)$ & $10,166(10,062)$ \\
\hline Trichiurus lepturus & Trichiuridae & $\mathrm{DP}$ & 152 & 19.17 & 14 & 66.67 & 23,311 & 32.26 & 3,479 \\
\hline Paralonchurus brasiliensis & Sciaenidae & $\mathrm{D}$ & 387 & 48.80 & 12 & 57.14 & 2,930 & 4.06 & 3,130 \\
\hline Mugil cf. liza* & Mugilidae & DP & 73 & 9.21 & 10 & 47.62 & 32,517 & 45.00 & 2,598 \\
\hline Urophycis brasiliensis & Phycidae & $\mathrm{D}$ & 28 & 3.53 & 11 & 52.38 & 2,847 & 3.94 & 399 \\
\hline Menticirrhus littoralis & Sciaenidae & $\mathrm{D}$ & 25 & 3.15 & 6 & 28.57 & 4,133 & 5.72 & 257 \\
\hline Umbrina canosai* & Sciaenidae & $\mathrm{D}$ & 13 & 1.64 & 3 & 14.29 & 3,560 & 4.93 & 95 \\
\hline Lycengraulis grossidens & Clupeidae & $\mathrm{P}$ & 25 & 3.15 & 3 & 14.29 & 353 & 0.49 & 54 \\
\hline Cynoscion guatucupa* & Sciaenidae & DP & 10 & 1.26 & 6 & 28.57 & 353 & 0.49 & 51 \\
\hline Macrodon atricauda* & Sciaenidae & $\mathrm{D}$ & 10 & 1.26 & 6 & 28.57 & 27 & 0.04 & 39 \\
\hline Micropogonia furnieri* & Sciaenidae & $\mathrm{D}$ & 5 & 0.63 & 4 & 19.05 & 458 & 0.63 & 25 \\
\hline Porichthys porosissimus & Batrachoididae & $\mathrm{D}$ & 18 & 2.27 & 1 & 4.76 & 1,446 & 2.00 & 21 \\
\hline Genidens sp. & Ariidae & $\mathrm{D}$ & 9 & 1.13 & 2 & 9.52 & 124 & 0.17 & 13 \\
\hline Stellifer rastrifer & Sciaenidae & $\mathrm{D}$ & 4 & 0.50 & 1 & 4.76 & 45 & 0.06 & 3 \\
\hline Pomatomus saltatrix* & Pomatidae & $\mathrm{P}$ & 2 & 0.25 & 1 & 4.76 & 145 & 0.20 & 2 \\
\hline Cynoscion jamaiscensis & Sciaenidae & $\mathrm{D}$ & 2 & 0.25 & 1 & 4.76 & 10 & 0.01 & 1 \\
\hline Unidentified teleosts** & & & 30 & 3.78 & 14 & 66.67 & - & - & - \\
\hline Cephalopods & & & 11 & $100(1.37)$ & 6 & 28.57 & 448 & $100(0.62)$ & $3,339(33)$ \\
\hline Doryteuthis plei & Loliginidae & DP & 6 & 54.55 & 4 & 19.05 & 397 & 88.85 & 2,731 \\
\hline Doryteuthis sanpaulensis & Loliginidae & DP & 3 & 27.27 & 3 & 14.29 & 37 & 8.27 & 508 \\
\hline Argonauta nodosa & Argonautidae & DP & 2 & 18.18 & 1 & 4.76 & 13 & 2.88 & 100 \\
\hline
\end{tabular}

* Species considered as overexploited by the Brazilian Ministry of the Environment (MMA, 2004).

** Prey remains not included in the IRI indexes.

difference was found in the percentage frequency of occurrence $(\% \mathrm{FO})$ of the top five important fish prey items (T. lepturus, P. brasiliensis, M. cf. liza, U. brasiliensis, $M$. littoralis) between the two periods tested (chi-squared test $=2.02, \mathrm{df}=4,0.25<p<0.5$ ), but a highly significant difference was found in the numerical contribution $(\% \mathrm{~N})$ of these prey items (chi-squared test $=1.036, \mathrm{df}=4$, $p<0.005$ ). As a consequence, the importance of some prey species such as $T$. lepturus increased from the first $(\% \mathrm{IRI}=17.2)$ to the second period $(\% \mathrm{IRI}=53.7)$, whereas the importance of $P$. brasiliensis dropped between the two periods (from \%IRI $=54.1$ to 5.3). Nevertheless, despite some variations in the IRI ranking positions, the top five fish prey species were the same for both periods.

Prey ecological analysis showed a preference for demersal and demersal-pelagic species, while the exclusively pelagic prey did not obtain high indices (Figure 1). Demersal prey appeared in high numbers, while demersal-pelagic species contributed with a large quantity of biomass.

The overall prey size distribution among the fish ranged from very small $(<50 \mathrm{~mm})$ weakfishes (Cynoscion spp.) to large (>1.200 mm) largehead hairtail (T. lepturus) $($ median $=118.60 ; \mathrm{SD}=225.90 ; \mathrm{n}=691)$ (Table 2). The size of cephalopods varied from 22.4 to $236.1 \mathrm{~mm}($ median $=94.6 ; \mathrm{SD}=72.43 ; \mathrm{n}=11)($ Table 2$)$. Overall, $75.2 \%$ of all teleosts (mainly $C$. jamaiscensis, Lycengraulis grossidens, M. atricauda, P. brasiliensis and Stellifer rastrifer) were smaller than $250 \mathrm{~mm}$ and only a few species (M. littoralis, M. cf. liza and T. lepturus) had a mean size larger than $250 \mathrm{~mm}$. Spearman's test showed a significant correlation between the total length of the bottlenose dolphin and the length of its pooled fish prey ( $\mathrm{rs}=0.38 ; \mathrm{gl}=436 ; p<0.05)$. The same trend, although not always significant, was observed when considering the size of the two most common fish prey species, $T$. lepturus 


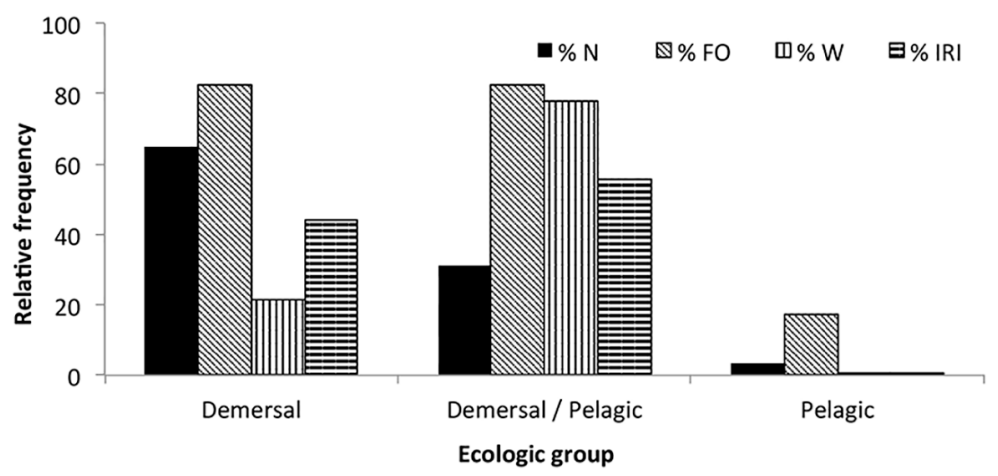

Figure 1. Importance of the different prey's ecological groups in the diet of common bottlenose dolphins from the northern coast of Rio Grande do Sul, southern Brazil, from 1991 to 2008. Key to abbreviations: percentage numerical frequency $(\% \mathrm{~N})$, percentage frequency of occurrence $(\% \mathrm{FO})$, percentage biomass $(\% \mathrm{~W})$, percentage index of relative importance $(\% \mathrm{IRI})$.

Table 2. Total length and biomass of prey as estimated from otoliths and cephalopod beaks found in the stomach contents of common bottlenose dolphins from the central-northern coast of Rio Grande do Sul, southern Brazil, from 1991 to 2008. Key to abbreviations: $\mathrm{N}=$ Number, Min. $=$ Minimum, Max. $=$ Maximum, $\mathrm{SD}=$ Standard deviation.

\begin{tabular}{|c|c|c|c|c|c|c|c|}
\hline \multirow[t]{2}{*}{ Prey species } & \multirow{2}{*}{$\begin{array}{c}\mathrm{N} \\
\text { Total (Measured*) }\end{array}$} & \multicolumn{3}{|c|}{ Total Length (mm) } & \multicolumn{3}{|c|}{ Biomass (g) } \\
\hline & & Min. & Max. & Mean (SD) & Min. & Max. & Mean (SD) \\
\hline \multicolumn{8}{|l|}{ Teleosts } \\
\hline Cynoscion guatucupa & $10(10)$ & 28.30 & 275.52 & $100.70(88.99)$ & 1.00 & 321.22 & $38.37(94.60)$ \\
\hline Cynoscion jamaiscensis & $2(2)$ & 32.27 & 68.20 & $50.24(25.40)$ & 2.72 & 6.97 & $4.85(3.00)$ \\
\hline Genidens sp. & $9(5)$ & 55.74 & 113.32 & $81.34(26.81)$ & 9.11 & 19.00 & $13.77(4.81)$ \\
\hline Lycengraulis grossidens & $25(22)$ & 53.77 & 222.89 & $105.74(54.67)$ & 0.50 & 88.10 & $15.79(28.0)$ \\
\hline Macrodon atricauda & $10(9)$ & 139.22 & 217.24 & $166.27(29.63)$ & 1.55 & 5.40 & $2.76(1.42)$ \\
\hline Menticirrhus littoralis & $25(25)$ & 167.56 & 316.73 & $251.61(39.80)$ & 50.18 & 280.24 & $165.30(71.92)$ \\
\hline Micropogonias furnieri & $5(5)$ & 75.45 & 272.98 & $237.21(90.60)$ & 7.00 & 194.80 & $91.67(82.02)$ \\
\hline Mugil cf. liza & $73(69)$ & 100.66 & 533.26 & $269.12(137.80)$ & 15.97 & 1771.8 & $417.9(442.22)$ \\
\hline Paralonchurus brasiliensis & $387(345)$ & 42.78 & 192.20 & $102.43(27.35)$ & 1.00 & 56.72 & $7.56(7.92)$ \\
\hline Pomatomus saltatrix & $2(2)$ & 88.53 & 254.04 & $171.28(117.02)$ & 4.12 & 140.95 & $72.53(96.74)$ \\
\hline Porichthys porosissimus & $18(17)$ & 112.73 & 226.37 & $186.31(26.92)$ & 57.18 & 122.08 & $85.07(27.20)$ \\
\hline Stellifer rastrifer & $4(4)$ & 101.77 & 120.72 & $116.00(9.47)$ & 7.10 & 12.59 & $11.22(2.74)$ \\
\hline Trichiurus lepturus & $152(90)$ & 112.73 & 1229.25 & $680.33(150.61)$ & 4.19 & 898.64 & $131.15(126.1)$ \\
\hline Umbrina canosai & $13(13)$ & 99.25 & 346.07 & $249.30(73.06)$ & 11.10 & 627.38 & $273.84(182.0)$ \\
\hline Urophycis brasiliensis & $28(25)$ & 45.00 & 407.00 & $196.66(101.3)$ & 1.00 & 578.41 & $105.74(154.4)$ \\
\hline \multicolumn{8}{|l|}{ Cephalopods } \\
\hline Argonauta nodosa & $2(2)$ & 22.40 & 39.90 & $31.10(12.4)$ & 2.40 & 10.50 & $6.45(5.7)$ \\
\hline Doryteuthis plei & $6(6)$ & 94.60 & 236.10 & $162.10(52.2)$ & 18.60 & 135.40 & $66.28(42.83)$ \\
\hline Doryteuthis sanpaulensis & $3(3)$ & 51.30 & 69.50 & $62.05(9.53)$ & 7.10 & 17.50 & $12.36(5.2)$ \\
\hline
\end{tabular}

* Otoliths that were severely eroded were counted but not used to estimate prey length and mass.

(rs $=0.014 ; \mathrm{gl}=114 ; p=0.441)$ and $P$. brasiliensis ( $\mathrm{rs}=0.323 ; \mathrm{gl}=189 ; p<0.001)$, showing that the largest dolphins tend to prey on the largest specimens of those species.

Considering all the prey taxa, the different ecological groups consumed by the bottlenose dolphin in southern
Brazil indicated a wide variation in foraging strategy in response to these different habitats and prey characteristics. Nevertheless, among all the groups, the sciaenid fishes are the most important prey. The great importance of this fish family could reflect both the abundance of the group in the region (e.g. HAIMOVICI et al., 1996) and the special 
foraging strategy used by the bottlenose dolphin, that is, its passive listening for prey-generated sounds (BARROS; WELLS, 1998; GANNON et al., 2005). Indeed, the sciaenids are considered one of the most active sound producers among fish (RAMCHARITAR et al., 2006).

The seasonal occurrence of cephalopods in the diet of bottlenose dolphins in southern Brazil is probably influenced by the warm currents in the region during the austral summer. This is particularly the case with $D$. plei, which penetrates from the north following the Brazilian Current (HAIMOVICI; PEREZ, 1991). Despite the piscivorous preference of $T$. truncatus, reported worldwide, the cephalopods comprise a significant portion of the diet of bottlenose dolphins on the Pacific coast of South America (VAN WAEREBEEK et al., 1990).

A positive correlation was found between the size of T. truncatus and the size of $P$. brasiliensis, T. lepturus and the size of all prey considered together. The correlations were not always significant, but overall results indicate that larger dolphins prey on larger prey items. This positive correlation between prey and predator size was also found for the species in other parts of the world (e.g. COCKCROFT; ROSS, 1990; BLANCO et al., 2001).

Although the ingestion of fishing gear by bottlenose dolphins during foraging behavior has been reported in some areas around the world (e.g. GORZELANY, 1998; GOMERCIC et al., 2009), the only case of fishing debris found in the stomach of a bottlenose dolphin in southern Brazil was probably a result of secondary ingestion.

Regarding possible interactions with fisheries, seven of the 15 fish species consumed by the bottlenose dolphins in southern Brazil are important to the medium-scale coastal fisheries: C. guatucupa, $M$. atricauda, $M$. littoralis, M. furnieri, M. cf. liza, U. canosai and $U$. brasiliensis (HAIMOVICI et al., 1996; MORENO et al., 2009; UNIVALI/CTTMar, 2010). On the other hand, $P$. brasiliensis, $P$. porosissimus and T. lepturus have no significant commercial value and are usually discarded by the fishing vessels operating on the Rio Grande do Sul coast (HAIMOVICI et al., 1996).

Nevertheless, at least four sciaenid prey species of T. truncatus in southern Brazil were already considered overexploited by the Brazilian Ministry of the Environment a decade ago (MMA, 2004), including the argentine croaker (U. canosai), the stripped weakfish (C. guatucupa), the king weakfish (M. atricauda, previously mentioned in the literature as M. ancylodon - see CARVALHO-FILHO et al., 2010) and the whitemouth croaker (M. furnieri)
(Table 1). It is interesting to note that a dietary study of franciscana dolphins, Pontoporia blainvillei, carried out in Rio Grande, southern Brazil, showed that the consumption of M. furnieri in the region has decreased over the years, whereas the importance of $T$. lepturus has increased, probably as a consequence of a shift in the abundance of these fish species (SECCHI et al., 2003). Based on these historical changes, the increase in the landings of mullet in southern Brazil in recent years is also of concern and may also lead to a future change in the diet composition of bottlenose dolphins. The fishing pressure on grey mullet (M. liza) has been even higher, since they are harvested mostly in their main spawning areas during the migration of the southern populations (LEMOS et al., 2014). In fact, overexploitation is considered to constitute a severe threat to this species in southern Brazil where the stock is feared to be on the edge of collapse (CASTRO et al., 2015).

Therefore, in view of the fact that fishing effort has increased greatly in southern Brazil over recent years (e.g. UNIVALI, 2010; OCCHIALINI et al., 2012) and that there is in general a low level of compliance with fishing regulations in the country (e.g. DIAS-NETO, 2010), a future change in the fish community can be expected. However, we cannot predict how these changes will be reflected in the diet of the bottlenose dolphin and, ultimately, on its conservation status. Future studies could help in elucidating whether the current commercial fishing effort may actually present a threat to the conservation status of the bottlenose dolphin in the area.

\section{ACKNOWLEDGMENTS}

This study was supported by the Conselho Nacional de Desenvolvimento Científico e Tecnológico (CNPq) through scholarships (Process numbers 572180/2008-0 and 26001/2009-2) and support from the research project "Mamíferos e Aves Marinhas da Costa do Rio Grande do Sul: Conservação e Monitoramento Ambiental" carried out by the Universidade Estadual do Rio Grande do Sul (UERGS). We would also thank all our colleagues of the Grupo de Estudos de Mamíferos Aquáticos do Rio Grande do Sul (GEMARS) for their help during the necropsies and collection of specimens. Logistical support was provided by the Centro de Estudos Costeiros, Limnológicos e Marinhos - CECLIMAR/UFRGS. This paper is part of the Bachelor's Thesis in Biological Sciences of Lucas Milmann de Carvalho at UERGS. The Research Group "Ecologia e Conservação de Organismos e Ambientes 
Aquáticos - ECOAqua/CNPq" contributed to this study. We would further thank Larissa de Oliveira, Koen Van Waerebeek and Karin Sachs who very kindly helped with their reviews to improve the manuscript.

\section{REFERENCES}

BARROS, N. B.; WELLS, R. S. Prey and feeding patterns of resident bottlenose dolphins (Tursiops truncatus) in Sarasota Bay, Florida. J. Mamm., v. 79, n. 3, p. 1045-1059, 1998.

BLANCO, C.; SALOMÓN, O.; RAGA, J. A. Diet of the bottlenose dolphin (Tursiops truncatus) in the western Mediterranean Sea. J. Mar. Biol. Assoc. UK, v. 81, n. 6, p. 1053-1058, 2001.

BOWEN, W. D. Reconstruction of pinniped diets: accounting for complete digestion of otoliths and cephalopod beaks. Can. J. Fish. Aquat. Sci., v. 57, n. 5, p. 898-905, 2000.

BOYD, W.; BOWEN, W. D.; IVERSON, S. J. Marine Mammal Ecology and Conservation: a Handbook of Techniques. Oxford: Oxford University Press, 2010. 450 p.

BRASIL. Ministério do Meio Ambiente. Instrução normativa IBAMA No. 05, de 21 de maio de 2004. Reconhece como espécies ameaçadas de extinção e espécies sobreexplotadas ou ameaçadas de sobreexplotação, os invertebrados aquáticos e peixes, constantes dos Anexos a esta Instrução Normativa. Brasília: Diário Oficial da União, 2004.

CARVALHO-FILHO, A. Peixes da costa brasileira. 3a. ed. São Paulo: Melro, 1999. 347 p.

CARVALHO-FILHO, A.; SANTOS, S.; SAMPAIO, I. Macrodon atricauda (Günther, 1880) (Perciformes: Sciaenidae), a valid species from the southwestern Atlantic, with comments on its conservation. Zootaxa, v. 2519, p. 48-58, 2010.

CASTRO, M. G.; VIEIRA, J. P.; BRICK PERES, M.; ALBIERI, R.; MENDONÇA, J. T.; VILLWOCK, M. L.; FADRÉ, N. N.; PADOVANI-FERREIRA, F.; DA SILVA, F. M. S.; RODRIGUES, A. M. T.; CHAO, L. Mugil liza. The IUCN Red List of Threatened Species 2015. Available: <www.iucnredlist.org>. Accessed: 14 Oct. 2015.

COCKCROFT, V. G.; ROSS, G. J. B. Food and feeding off southern Natal, South Africa. In: LEATHERWOOD, S.; REEVES, R. R. (Eds.). The bottlenose dolphin. San Diego: Academic Press, 1990. p. 295-308.

CORTÉS, E. A critical review of methods of studying fish feeding based on analysis of stomach contents: application to elasmobranches fishes. Can. J. Fish. Aquat. Sci., v. 54, n. 3, p. 726-738, 1997.

DAURA-JORGE, F. G.; INGRAM, S. N.; SIMÕES-LOPES, P. C. Seasonal abundance and adult survival of bottlenose dolphins (Tursiops truncatus) in a community that cooperatively forages with fishermen in southern Brazil. Mar. Mamm. Sci., v. 29, n. 2, p. 293-311, 2013.

DIAS-NETO, J. Gestão do uso dos recursos pesqueiros marinhos no Brasil. 2nd. ed. Brasília: Ministério do Meio Ambiente, Instituto Brasileiro do Meio Ambiente e dos Recursos Naturais Renováveis, 2010. 242 p.

DI BENEDITTO, A. M.; RAMOS, R. M. A.; SICILIANO, S.; SANTOS, R. A.; BASTOS, G.; FAGUNDES-NETTO, E. Stomach contents of delphinids from Rio de Janeiro, southeastern Brazil. Aquat. Mamm., v. 27, n. 1, p. 24-28, 2001.

DI TULLIO, J. C.; FRUET, P. F.; SECCHI, E. R. Identifying critical areas to reduce bycatch of coastal common bottlenose dolphins
Tursiops truncatus in artisanal fisheries of the subtropical western South Atlantic. Endang. Species. Res., v. 29, n. 1, p. 35-50, 2015.

DUNSHEA, G.; BARROS, N. B.; BERENS MCCABE, E. J.; GALES, N. J.; HINDELL, M. A.; JARMAN, S. N.; WELLS, R. S. Stranded dolphin stomach contents represent the free-ranging population's diet. Biol. Lett., v. 9, n. 3, 5 p., 2013.

FRUET, P. F.; KINAS, P. G.; DA SILVA, K. G.; DI TULLIO, J. C.; MONTEIRO, D. S.; DALLA ROSA, L.; ESTIMA, S. C.; SECCHI, E. R. Temporal trends in mortality and effects of by catch on common bottlenose dolphins, Tursiops truncatus, in southern Brazil. J. Mar. Biol. Assoc. UK, v. 92, n. 8, p. 18651876, 2012.

GANNON, D. P.; BARROS, N. B.; NOWACEK, D. P.; READ, J. A.; WAPLES, D. M.; WELLS, R. S. Prey detection by bottlenose dolphins, Tursiops truncatus: an experimental test of the passive listening hypothesis. Anim. Behav., v. 69, n. 3, p. 709-720, 2005.

GOMERČIĆ, M. D.; GALOV, A.; GOMERČIĆ, T.; ŠKRTIĆ, D.; ĆURKOVIĆ, S.; LUCIĆ, H.; VUKOVIĆ, S.; ARBANASIĆ, H.; GOMERČIĆ, H. Bottlenose dolphin (Tursiops truncatus) depredation resulting in larynx strangulation with gill-net parts. Mar. Mamm. Sci., v. 25, n. 2, p. 392-401, 2009.

GOODALL, R. N. P.; MARCHESI, M. C.; PIMPER, L. E.; DELLABIANCA, N.; BENEGAS, L. G.; TORRES, M. A.; RICCIALDELLI, L. Southernmost records of bottlenose dolphins, Tursiops truncatus. Polar Biol., v. 34, n. 7, p. 10851090, 2011.

GORZELANY, J. F. Unusual deaths of two free-ranging Atlantic bottlenose dolphins (Tursiops truncatus) related to ingestion of recreational fishing gear. Mar. Mamm. Sci., v. 14, n. 3, p. 614-617, 1998.

GURJÃO, L. M.; FORTUNATO NETO, M. A. A.; SANTOS, R. A.; CASCON, P. Análise de conteúdos estomacais de quatro golfinhos (Cetacea: Delphinidae) encalhados em praias no litoral do Estado do Ceará, Brasil. Rev. Biocienc., v. 10, n. 1-2, p. 39-45, 2004.

HAIMOVICI, M.; MARTINS, A. S.; VIEIRA, P. C. Distribuição e abundância de peixes teleósteos demersais sobre a plataforma continental do sul do Brasil. Rev. Bras. Biol., v. 56, n. 1, p. 27-50, 1996.

HAIMOVICI, M.; VELASCO, G. Lenght-weight relationship of marine fishes from southern Brazil. Naga ICLARM Quat., v. 23, n. 1, p. 19-23, 2000.

HAIMOVICI, M.; PEREZ, J. A. A. Coastal cephalopod fauna of Southern Brazil. Bull. Mar. Sci., v. 49, n. 1-2, p. 221-230, 1991.

HAIMOVICI, M.; KLIPPEL, S. Diagnóstico da biodiversidade dos peixes teleósteos demersais marinhos e estuarinos do Brasil. In: Workshop para avaliação e ações prioritárias para a conservação da biodiversidade das zonas costeira e marinha do Brasil. Technical Report (CD-ROM). Brasília: Ministério do Meio Ambiente, 2002.

KASCHNER, K.; PAULY, D. Competition between marine mammals and fisheries: Food for thought. In: SALEM, D. J.; ROWAN, A. N. (Eds.). The state of the animals III. Washington: Humane Society Press, 2005. p. 95-117.

LEMOS, V. M.; VARELA JR, A. S.; SCHWINGEL, P. R.; MUELBERT, J. H.; VIEIRA, J. P. Migration and reproductive biology of Mugil liza (Teleostei: Mugilidae) in south Brazil. J. Fish Biol., v. 85, n. 3, p. 671-687, 2014. 
MELO, C. L. C.; SANTOS, R. A.; BASSOI, M.; ARAÚJO, A. C.; LAILSON-BRITO, J.; DORNELES, P. R.; AZEVEDO, A. F. Feeding habits of delphinids (Mammalia: Cetacea) from Rio de Janeiro State, Brazil. J. Mar. Biol. Assoc. UK, v. 90, n. 8, p. 1509-1515, 2010.

MENEZES, N. A.; FIGUEIREDO, J. L. Manual de peixes marinhos do sudeste do Brasil. IV. Teleostei (3). São Paulo: Museu de Zoologia da USP, 1980. 96 p.

MORENO, I. B.; TAVARES, M.; DANILEWICZ, D.; OTT, P. H.; MACHADO, R. Descrição da pesca costeira de média escala no litoral norte do Rio Grande do Sul: comunidades pesqueiras de Imbé/Tramandaí e Passo de Torres/Torres. Bol. Inst. Pesca., v. 35, n. 1, p. 129-140, 2009.

OCCHIALINI, D. S.; RODRIGUES, A. M. T.; KOTAS, J. E. Caracterização e análise comparativa da pesca industrial de emalhe-de-fundo costeiro, considerando a evolução física da frota a partir de1995 e a produção pesqueira entre 2001 e 2010. Rev. CEPSUL - Biodivers. Conserv. Mar., v. 3, n. 1, p. 1-21, 2012.

PINKAS, L.; M. S. OLIPHANT.; IVERSON I. L. K. Food habits of albacore, bluefin tuna, and bonito in Californian waters. Fish Bull., v. 152, p. 1-105, 1971.

RAMCHARITAR, J.; GANNON, D. P.; POPPER, A. N. Bioacoustics of the fishes of the Family Sciaenidae (croakers and drums). Trans. Am. Fish. Soc., v. 135, n. 5, p. 1409-1431, 2006.

RIO GRANDE DO SUL (estado). Provincial Decree No 51.797, from 08 September 2014, of the state of Rio Grande do Sul, Brazil, related to endangered wildlife species. Porto Alegre, 2014.

ROSSI-WONGTSCHOWSKI, C. L. B.; SILIPRANDI, C. C.; BRENHA, M. R.; GONSALES, S. A.; SANTIFICETUR, C.; VAZ-DOS-SANTOS, A. M. Atlas of marine bony fish otoliths (sagittae) of southeastern-southern Brazil Part I: Gadiformes (Macrouridae, Moridae, Bregmacerotidae, Phycidae and merlucciidae); Part II: Perciformes (Carangidae, Sciaenidae, Scombridae and Serranidae). Braz. J. Oceanogr., v. 62, n. 1, p. 1-103, 2014.

SANTOS, R. A.; HAIMOVICI, M. Trophic relationships of the long-finned squid Loligo sanpaulensis on the southern Brazilian shelf. Afr. J. Mar. Sci., v. 20, p. 1-19, 1998.

SANTOS, R. A.; HAIMOVICI, M. Cephalopods in the diet of marine mammals stranded or incidentally caught along southeastern and southern Brazil (21-34 ${ }^{\circ}$ S). Fish. Res., v. 52, p. 99-112, 2001.

SANTOS, M. C. O.; ROSSO, S.; SANTOS, R. A.; LUCATO, S. H. B.; BASSOI, M. Insights on small cetacean feeding habits in southeastern Brazil. Aquat. Mamm., v. 28, n. 1, p. 38-45, 2002.

SECCHI, E. R.; OTT, P. H.; DANILEWICZ, D. Effects of fishing by-catch and conservation status of the franciscana dolphin, Pontoporia blainvillei. In: GALES, N.; HINDELL, M.; KIRKWOOD, K. (Eds.). Marine Mammals: Fisheries, Tourism and Management Issues. Collinwoop: CSIRO Publishing, 2003. p. 174-191.
SICILIANO, S.; EMIM-LIMA, N. R.; COSTA, A. F.; RODRIGUES, A. L. F.; MAGALHÃES, F. A.; TOSI, C. H.; GARRI, R. G.; SILVA, C. R.; SILVA JR, J. S. E. Revisão do conhecimento sobre os mamíferos aquáticos da costa norte do Brasil. Arq. Mus. Nac., v. 66, n. 2, p. 381-401, 2008.

SIMÕES-LOPES, P. C. Interaction of coastal populations of Tursiops truncatus (Cetacea, Delphinidae) with the mullet artisanal fisheries in Southern Brazil. Biotemas, v. 4, n. 2, p. 83-94, 1991.

SIMÕES-LOPES, P. C.; FABIÁN, M. E.; MENEGHETI, J. O. Dolphin interactions with the mullet artisanal fishing on southern Brazil: A qualitative and quantitative approach. Rev. Bras. Zool., v. 15, n. 3, p. 709-726, 1998.

UNIVALI/CTTMar. Boletim estatístico da pesca industrial de Santa Catarina - ano 2009 e panorama 2000 - 2009. Programa de monitoramento e avaliação da atividade pesqueira industrial no sudeste e sul do Brasil. Universidade do Vale do Itajaí, Centro de Ciências Tecnológicas da Terra e do Mar. Itajaí, 2010. 97 p.

VAN BRESSEM, M. F.; VAN WAEREBEEK, K.; REYES, J. C.; FÉLIX, F.; ECHEGARAY, M.; SICILIANO, S.; DI BENEDITTO, A. P.; FLACH, L.; VIDDI, F.; AVILA, I. C.; HERRERA, J. C.; TOBÓN, I. C.; BOLAÑOS-JIMENEZ, J.; MORENO, I. B.; OTT, P. H.; SANINO, G. P.; CASTINEIRA, E.; MONTES, D.; CRESPO, E.; FLORES, P.A. C.; HAASE, B.; MENDONÇA DE SOUZA, S. M. F.; LAETA, M.; FRAGOSO, A. B. A preliminary overview of skin and skeletal diseases and traumata in small cetaceans from South American waters. Latin Am. J. aquatic Mamm, v. 6, n. 1, p. 7-42, 2007.

VAN BRESSEM, M.F.; SIMÕES-LOPES, P. C.; FÉLIX, F.; KISZKA, J. J.; DAURA-JORGE, F. G.; AVILA, I. C.; SECCHI, E. R.; FLACH, L.; FRUET, P. F.; DU TOIT, K.; OTT, P. H.; ELWEN, S.; DI GIACOMO, A. B.; WAGNER, J.; BANKS, A; VAN WAEREBEEK, K. Epidemiology of lobomycosislike disease in bottlenose dolphins Tursiops spp. from South America and southern Africa. Dis. Aquat. Organ., v. 117, n. 1, p. 56-75, 2015.

VAN WAEREBEEK, K.; REYES, J. C.; READ, A. J.; MCKINNON, J. S. Preliminary observations of bottlenose dolphins from the Pacific coast of South America. In: LEATHERWOOD, S.; REEVES, R. R. (Eds.). The bottlenose dolphin. San Diego: Academic Press, 1990. p. 143-154, 1990.

WAESSLE, J. A.; LASTA, C. A.; FAVERO, M. Otolith morphology and body size relationships for juvenile Sciaenidae in the Río de la Plata estuary $\left(35-36^{\circ}\right.$ S). Sci. Mar., v. 67, n. 2, p. 233-240, 2003.

WELLS, R. S.; SCOTT, M. D. Bottlenose dolphins Tursiops truncatus and T. aduncus. In: PERRIN, W. F.; WÜRSIG, B.; THEWISSEN, J. G. M. (Eds.). Encyclopedia of Marine Mammals. 2nd ed. San Diego: Academic Press, 2009. p. 249-254.

ZAPPES, C. A.; ANDRIOLO, A.; P. SIMÕES-LOPES, P. C.; DI BENEDITTO, A. P. M. Human-dolphin (Tursiops truncatus Montagu, 1821) cooperative fishery and its influence on cast net fishing activities in Barra de Imbé/ Tramandaí, Southern Brazil. Ocean Coast. Manag., v. 54, n. 5, p. 427-432, 2011. 
